Imágenes en Urología

\title{
Calcificación unilateral de deferente y vesícula seminal
}

Mário J. Alves de Oliveira, Vítor Hugo Nogueira, Miguel Gomes Oliveira Mendes, Américo Ribeiro dos Santos

Serviço de Urologia, Hospital de São Marcos, Braga, Portugal.

$\mathrm{V}$ arón, 51 años, con antecedentes personales de diabetes mellitus e agenesía renal izquierda. En evaluación por cólico nefrítico derecho, descubierta calcificacion unilateral en el trayecto del deferente y vesícula seminal derechos, así como agenesía contralateral de las respectivas estructuras. La calcificación de los deferentes es un hallazgo infrecuente, coexistiendo de manera más usual en pacientes con diabetes. En la literatura no se encuentran descripciones previas de calcificación unilateral de los deferentes.

Correspondencia autor: Mário J. Alves de Oliveira Servicio de Urologia. Hospital de São Marcos. Apartado 2242 - 4701-965 Braga (Portugal)

E-mail autor: mario_oliv@yahoo.com Información artículo: Imágenes en Urología

Trabajo recibido: junio 2007

Trabajo aceptado: julio 2007
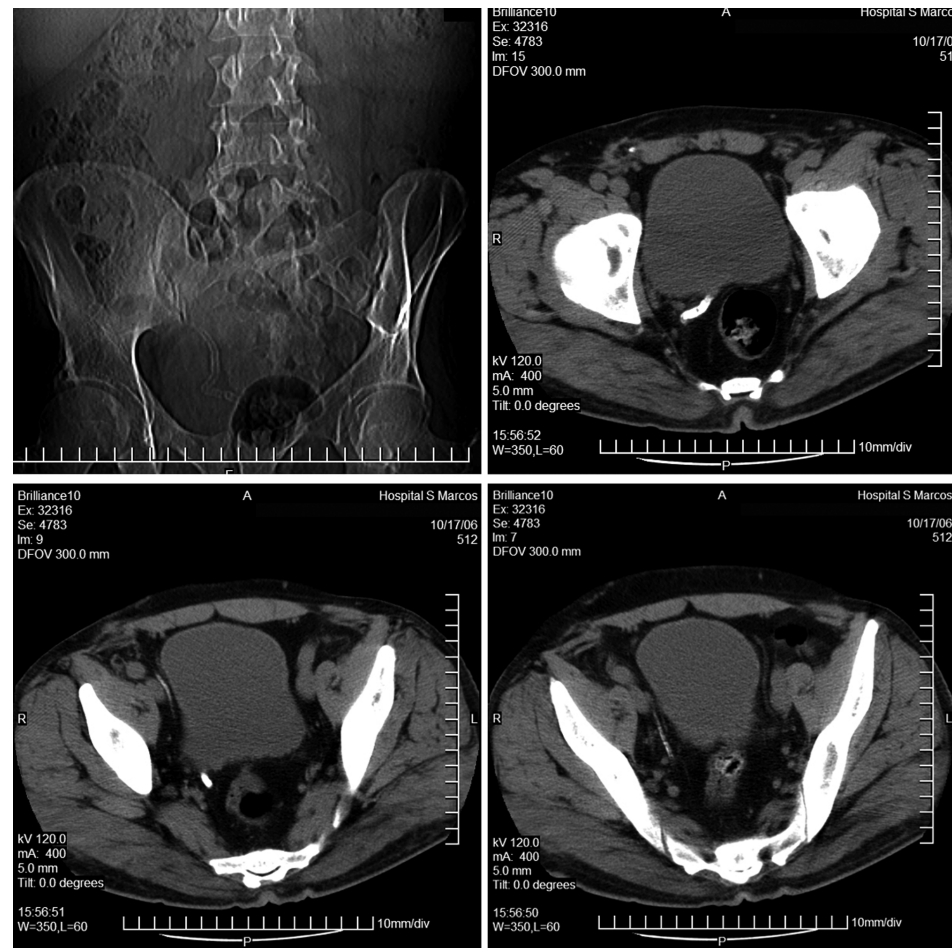

FIGURA 1 